TITLE:

\title{
BIOLOGICAL STUDIES OF A LITTORAL MUSSEL, HORMOMYA MUTABILIS (GOULD) I. PRELIMINARY OBSERVATIONS ON THE MOVING ABILITY
}

\author{
$\operatorname{AUTHOR}(S)$ :
}

Senawong, Chokechai

\section{CITATION:}

Senawong, Chokechai. BIOLOGICAL STUDIES OF A LITTORAL MUSSEL, HORMOMYA MUTABILIS (GOULD) I. PRELIMINARY OBSERVATIONS ON THE MOVING ABILITY.

PUBLICATIONS OF THE SETO MARINE BIOLOGICAL LABORATORY 1970, 18(4): 233-242

\section{ISSUE DATE:}

1970-12-15

URL:

http://hdl.handle.net/2433/175638

RIGHT: 


\title{
BIOLOGICAL STUDIES OF A LITTORAL MUSSEL, HORMOMYA MUTABILIS (GOULD) I. PRELIMINARY OBSERVATIONS ON THE MOVING ABILITY' ${ }^{1)}$
}

\author{
Chokechat SENAWONG \\ Seto Marine Biological Laboratory, Sirahama, Japan
}

With 4 Text-figures

\section{Introduction}

Hormomya mutabilis (Gould) is one of the littoral mussels of the family Mytilidae, which is found commonly along the coasts of the temperate to subtropical regions of Japan. Its distribution is extended, according to Kuroda and HABE (1952, p. 15), from $23^{\circ} \mathrm{N}$ to $35^{\circ} \mathrm{N}$ on the Pacific side and up to $36^{\circ} \mathrm{N}$ on the Japan Sea side in the Japanese waters, and further southerly to the waters of Formosa and the Philippines. Especially, this small littoral mussel, usually up to $40 \mathrm{~mm}$ in shell length, is the commonest lamellibranch found abundantly throughout the rocky shores of the sand stone in the vicinity of Seto, Kii Peninsula, middle Japan.

There, the mussel occurs in a number of dense colonies of variable sizes (Fig. 1), from several centimeters to several meters across or more, which are formed generally in very shallow places of the sublittoral zone and in lower parts of the intertidal zone, though very rarely some small colonies may be seen at rather higher levels in some special sites. Further, those colonies are seemingly confined to the even substrata. horizontal to slight sloping, but they are hardly found on very steep surface or on cliff. In forming colonies, the mussels attach to the substratum and to one another tightly by byssus to form compact aggregations.

The author has got familiar with this mussel since he visited Hatakezima Island in Tanabe Bay in May 1970, which is conserved as a biological experimental field for the Seto Marine Biological Laboratory, to start his marine biological studies at the Laboratory. He was much impressed by rich and variable intertidal fauna of the island, but most deeply at that any biological data were nearly unavailable on this mussel which must probably be the most dominant animal near the foot of every rocky intertidal area in the island. With some important mussels in the waters of Thailand in his mind, he has been inclined to start the biological study of littoral mussels in the vicinity, especially of the commonest member $H$. mutabilis.

1) Contributions from the Seto Marine Biological Laboratory, No. 530.

Publ. Seto Mar. Biol. Lab., XVIII, (4), 233-242, 1970. (Article 18) 
It may be natural that the author set out to work on this mussel with the researches of the environmental factors of the site of its colonies and of the mechanisms of colony formation. Then, in relation to the settling of spats, it was planned to trace the life history of the mussel by rearing larvae in the laboratory. For the first step of the plan, some tests were made to induce the spawning artificially. Trying to induce the spawning of the mussel after the method adopted by Loosanofr and Davis (1963) for Mytilus edulis, he placed 10 mussels separately in a glass bowl after the operation of pricking their adductor muscle gently with a sharp cleaned needle on June 11, this year. This was unsuccessful, but to his astonishment, it was found in the next morning that the mussels were fixed aggregated in a few groups. They must have moved from a scattered state to an aggregated state. Several suppositions may be presented as to the colony formation of this mussel, but the moving ability of the mussel, noticed here, might be an effectual factor to achieve the dense aggregate in nature. The moving ability itself has been known of some mussels and pearl oysters already (for instance see HARger 1970). However, to confirm the ability more in detail and to learn its effect on the formation of dense colonies in H. mutabilis, some preliminary experiments were made in June through August. The present short paper is prepared to note the results of these experiments.

The author owes Dr. T. Tokroka and Dr. S. Nishimura of the Seto Marine Biological Laboratory thanks for their help and advices given him incessantly during this study.

\section{Material and methods}

A considerable number of $H$. mutabilis were brought from the shore of Hatakezima Island to the laboratory at times during the observations from May 21 to August 31, 1970. The mussels collected were kept alive in the laboratory in a tank with running sea-water at room temperature to be used for experiments at hand. In order to unify the physiological condition of mussels experimented with as far as possible, mussels were used within 24 hours after collection. To fit this, an additional source of mussels was searched for near the laboratory, just on the north shore of the laboratory ground. The relation between the age and the shell size as well as the state of acclimatization in this mussel will differ from colony to colony. To check the errors which might be caused by these, strictly mussels of the same size range collected from the same single colony were used for respective experiments. As the shell length of this mussel ranged from 2 to $40 \mathrm{~mm}$ in the field during the time of observations, mussels in the size range of 2 to $5 \mathrm{~mm}$ were tentatively taken as juveniles and those larger than $15 \mathrm{~mm}$ were regarded as adults.

Efforts were paid not to injure the mussels for experiments. Mussels were detached from the rock surface very carefully by inserting a scraper under a part of their colony to cut their byssi at or very near the distal end, or rather to scrape 


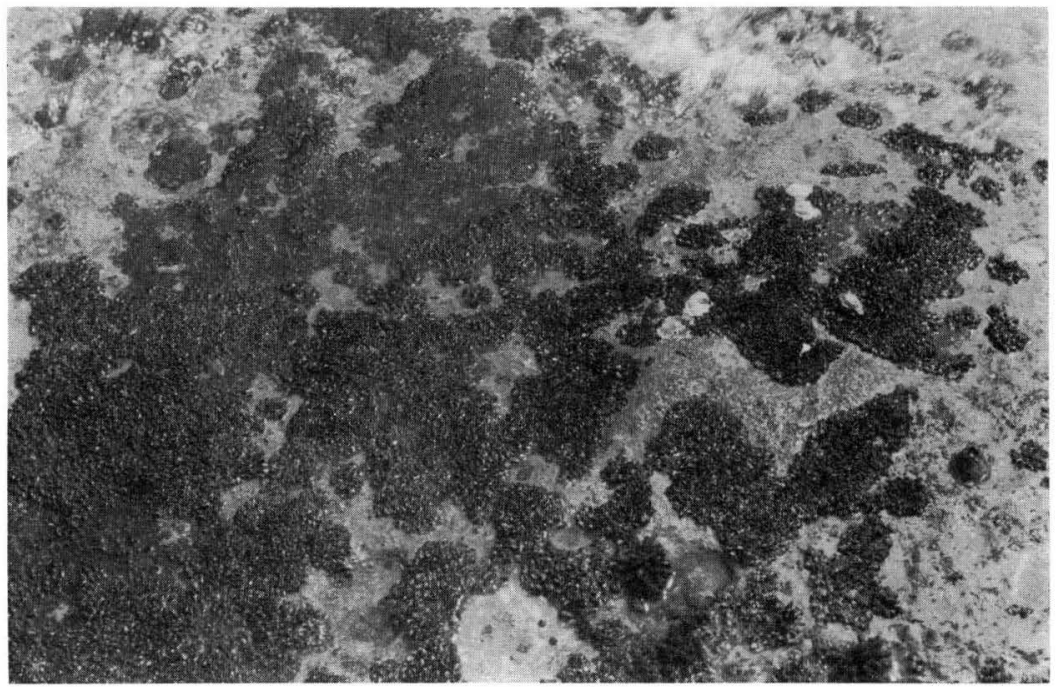

Fig. 1. A part of the zone near the low water mark occupied by colonies of Hormomya mutabilis (GoulD); on the north shore of the laboratory ground.

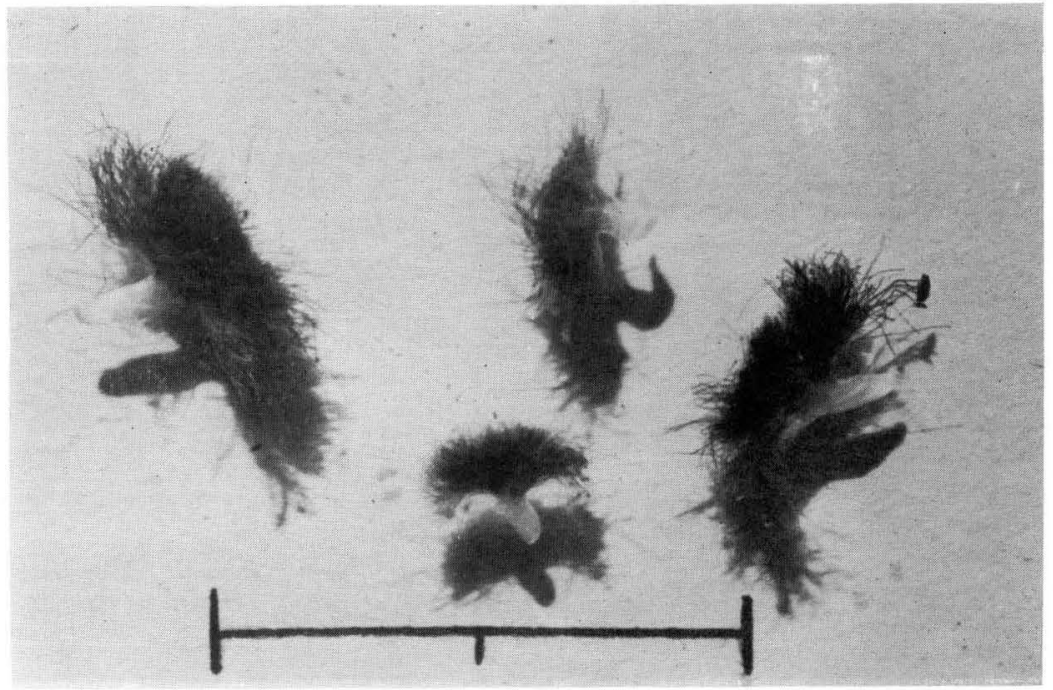

Fig. 2. Released byssi of Hormomya mutabilis (Gould), the scale represents $20 \mathrm{~mm}$. Byssi were cut straight by scissors when the mussels were separated from the colony. The root of byssus can be seen rather clearly by its shadow. 


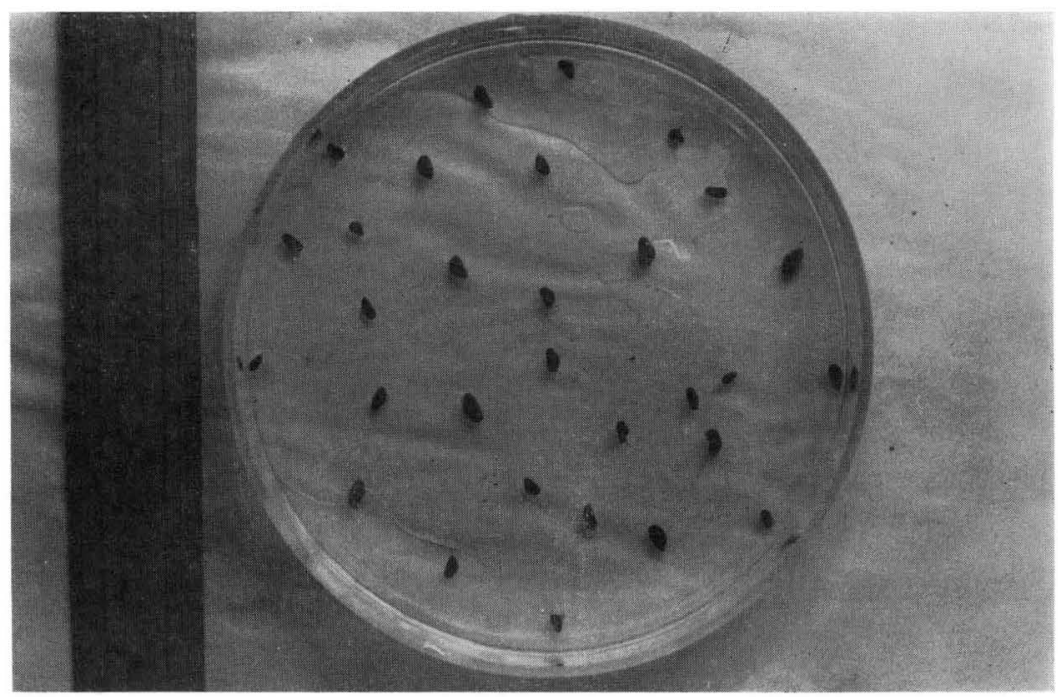

Fig. 3. Three to $6 \mathrm{~mm}$ long mussels arranged evenly in a petridish in Experiment VII shown in Table 3.

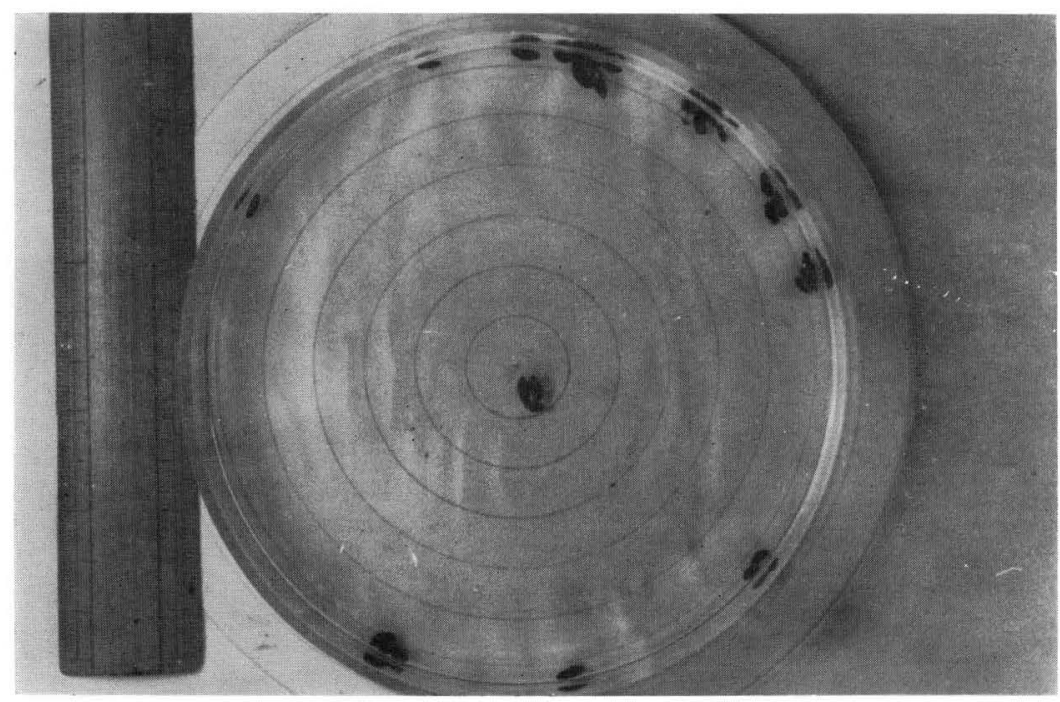

Fig. 4. Distribution of mussels after 24 hours in Experiment VII shown in Table 3, the dish is placed on a sheet of paper with circles at intervals of $10 \mathrm{~mm}$. 
away the substratum surface without giving any harm to byssi. The aggregates of mussels thus collected were left as they were till the time of experiments; individual mussels were separated from one another just before respective experiments by cutting byssi by scissors and the shell surface was cleaned.

It was planned to carry out the experiments for three purposes, (1) to confirm the moving ability and to learn the degree of activity and moving speed, (2) to find any trends toward aggregation, and (3) to analyse the trend into tropism if it was recognized. All the experiments were made at room temperature which fluctuated between $21^{\circ} \mathrm{C}$ and $34^{\circ} \mathrm{C}$.

The first series of experiments was designed to confirm the moving ability, to show in any way the moving activity, and to measure the moving speed of the mussel. To grade the moving activity, a mussel was placed laterally on either shells in a pertidish and the time intervals from the moment of its being placed in the dish to the first appearance of the foot outside the shell and then to the start of crawling were checked; this was repeated on 30 mussels of different sizes. For the measurements of moving speed, some mussels were placed on their ventral side at the center of a petridish laid on a sheet of white paper on which several concentric circles were drawn to read easily the distance moved from the center (Fig. 4). A smaller dish, $75 \mathrm{~mm}$ in diameter, set on the mat paper with circles at intervals of $5 \mathrm{~mm}$ was used for juveniles, and a larger dish, 120 in diameter, was laid on the mat with circles at intervals of $10 \mathrm{~mm}$ for adults. The moving speed was measured within 2 hours after the mussels were placed at the center of the dish, solely on the individuals which generally moved straight radially in uniform pace and without any significant pauses. The actual time of observation spent for respective mussels was $2^{\prime}$ to $9^{\prime} 11^{\prime \prime}$. During the observations, no running sea-water was supplied to keep the circumstances quiet in the dish.

The second series of experiments was designed to see whether or not any trend toward aggregation was existing. The mussels were placed evenly scattered in the dish (Fig. 3) which was supplied with very gently flowing sea-water which would never evoke any unusual movement nor check the usual movement of mussels. The distribution of mussels in the same dish was checked 24 hours after the mussels were arranged in that dish. Later the changes found in the distribution of mussels in 24 hours were compared with one another to see the trend.

The last series of experiments was designed to see if any tropism or tropisms, such as phototaxis, chemotaxis, thigmotaxis or stereotaxis, or rugotaxis, might be concerned with the trend toward aggregation. As in the second series of experiments, mussels and some pieces of rock, pebbles, or fragments of worn empty shells were placed together in the same dish evenly scattered and the distribution of mussels was checked after 24 hours to see if they moved preferably toward any special objects. The nonliving objects placed in the dish were all not so big, rather they were small, thin, and flat in size and shape. 


\section{Result of observations}

Crawling behaviour of $H$. mutabilis: The mussels ready to move will relax their adductor muscles first, and this results in the appearance of a very narrow slit between the shells on the ventral side. At the same time, two layers of thin mantle will appear from along the margin of respective shells and the dorsal exhalent siphon will be protruded out of the shell at the postero-dorsal corner. The ventral inhalent siphon will come outside the shell, too, but much less conspicuously than the exhalent siphon.

When the mussels are laid laterally on either side or laid on their dorsal side, they will extend out their long cylindrical foot from the anterior half of the slit mentioned above to reach the substratum by the tip of the foot. The foot tip will stick to the substratum. Then, by the help of muscle contraction of the foot, the mussels will rise or stand up on the ventral side; the position that is ready to crawl.

The crawling of the mussels is done by repeating the behaviour something like the above-mentioned rising behaviour of the mussel. The foot is extended ahead as far as possible and fixed to the substratum at the tip, then follows the contraction of the foot muscle, which will drag the body toward the tip of the foot. The extension of the foot is usually directed anteriorly or antero-laterally. The results of observations to show the moving activity are given in Table 1 .

The results of observations made on about 20 individuals (Table 2) show that juveniles or smaller mussels can move more actively than adults or larger mussels, and that the approximate speed of crawling is about $12.57 \mathrm{~mm}$ per minute in juveniles, but less than $7 \mathrm{~mm}$ per minute in adults under the same conditions.

Trend toward aggregation: The results of the second series of experiments (Table 3 ) seem to show that the mussels more or less tend to form aggregations by crawling. The individuals once settled in 24 hours are seemingly very stable regardless of the solitary and aggregated states, maintaining their sites steadily at least for a week or more. Tropism: As far as the present experiments are concerned, in forming aggregations no preference for special objects has been perceived by the author's eyes. A supplementary experiment was made to compare the possible effects of the rough substratum with those of the smooth glass surface of the petridish, by repeating the similar treatment of mussels on a rough cement substratum, but no significant differences were recognized. At present, the formation of aggregates seems superficially to be the result of a series of random movements of mussels. If, in more crucial experiments, the statistical analyses prove that the proportion of aggregated individuals is larger than that calculated upon the series of random movements, then some tropisms will have to be checked again in more exact ways.

\section{Discussions}

Rather active movement of Hormomya mutabilis confirmed here results, at least 
Table 1. Some measurements to grade the moving activity of $H$. mutabilis.

The material for the experiment was collected on the morning of August 28, 10:00-11:30 A. M., and the observations were made limitedly in the afternoon, 2:00-10:00 P.M., at room temperature $30^{\circ}-33^{\circ} \mathrm{C}$. The mussels were placed laterally on either shells. Some larger ones, marked with asterisk, extended their foot outside the shell, but could not rise up to start crawling.

\begin{tabular}{|c|c|c|c|c|c|}
\hline \multirow{3}{*}{$\frac{\text { Observation No. }}{1}$} & \multirow{3}{*}{$\begin{array}{l}\text { Shell length } \\
\text { in } \mathrm{mm} \\
\frac{3.0}{3}\end{array}$} & \multicolumn{4}{|c|}{$\begin{array}{l}\text { Time from the moment of placing the specimen } \\
\text { in the petridish to }\end{array}$} \\
\hline & & \multicolumn{2}{|c|}{$\begin{array}{l}\text { the first appearance } \\
\text { of foot outside the shell }\end{array}$} & \multicolumn{2}{|c|}{$\begin{array}{l}\text { the beginning of } \\
\text { crawling }\end{array}$} \\
\hline & & $1 \mathrm{~min}$ & $5 \mathrm{sec}$ & $1 \mathrm{~min}$ & $36 \mathrm{sec}$ \\
\hline 2 & 3.0 & 2 & 12 & 3 & 32 \\
\hline 3 & 3.5 & 1 & 22 & 2 & 15 \\
\hline 4 & 3.5 & 2 & 25 & 3 & 3 \\
\hline 5 & 4.0 & 5 & 32 & 7 & 2 \\
\hline 6 & 4.0 & 3 & 20 & 3 & 48 \\
\hline 7 & 4.0 & 3 & 46 & 4 & 55 \\
\hline 8 & 4.5 & 2 & 30 & 5 & 5 \\
\hline 9 & 5.0 & 1 & 45 & 2 & 30 \\
\hline 10 & 5.0 & 3 & 45 & 4 & 52 \\
\hline 11 & 5.0 & 3 & 40 & 5 & 7 \\
\hline 12 & 6.5 & 2 & 55 & 6 & 34 \\
\hline 13 & 6.5 & 2 & 3 & 4 & 45 \\
\hline 14 & 7.0 & 6 & 30 & 8 & 17 \\
\hline 15 & 7.0 & 18 & 5 & 19 & - \\
\hline 16 & 7.0 & 7 & 50 & 14 & 53 \\
\hline 17 & 8.0 & 13 & 28 & 15 & 52 \\
\hline 18 & 9.0 & 5 & 15 & 10 & 30 \\
\hline 19 & 9.0 & 2 & 45 & 5 & 9 \\
\hline 20 & 10.0 & 12 & 10 & 67 & 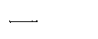 \\
\hline 21 & 12.5 & 5 & 25 & 26 & - \\
\hline $22 *$ & 14.0 & 10 & 5 & - & - \\
\hline $23 *$ & 17.0 & 21 & 10 & - & - \\
\hline $24 *$ & 18.0 & 4 & 5 & - & - \\
\hline 25 & 20.0 & 3 & 5 & 11 & 40 \\
\hline $26^{*}$ & 23.0 & 17 & 20 & - & - \\
\hline 27 & 28.0 & 25 & - & 110 & - \\
\hline $28 *$ & 29.0 & 32 & 30 & - & - \\
\hline $29 *$ & 34.0 & 16 & 45 & - & - \\
\hline $30^{*}$ & 40.0 & 14 & - & - & - \\
\hline
\end{tabular}

The time needed for the first appearance of foot outside the shell was $2 \mathrm{~min} 51 \mathrm{sec}$ and that for the start of crawling was $3 \mathrm{~min} 59 \mathrm{sec}$ on an average for 11 juveniles with shell length up to $5.0 \mathrm{~mm}$. Similarly, the average time for the appearance of foot outside the shell was $7 \mathrm{~min}$ $38.6 \mathrm{sec}$ and that for the start of first crawling was $17 \mathrm{~min} 48 \mathrm{sec}$ on an average for 10 mussels 6.5 to $12.5 \mathrm{~mm}$ in shell length. 
Table 2. Measurements of the moving speed of $H$. mutabilis.

The material for experiment was collected on the morning of August 15, 10:00-11:00 A.M., and the observations were made limitedly in the afternoon, 1:00-5:00 P. M., at room temperature $31^{\circ}-34^{\circ} \mathrm{C}$.

\begin{tabular}{|c|c|c|c|c|}
\hline $\begin{array}{c}\text { Observation } \\
\text { No. }\end{array}$ & $\begin{array}{l}\text { Shell length } \\
\text { in } \mathrm{mm}\end{array}$ & $\begin{array}{l}\text { Time span of } \\
\text { observation }\end{array}$ & $\begin{array}{l}\text { Distance moved } \\
\text { in mm } \\
\text { (approximate) }\end{array}$ & $\begin{array}{c}\text { Average speed } \\
\mathrm{mm} / \mathrm{min}\end{array}$ \\
\hline 1 & 2.0 & $2 \mathrm{~min} 18 \mathrm{sec}$ & 30 & 13.0 \\
\hline 2 & 2.5 & $2^{\prime} \quad 5^{\prime \prime}$ & 30 & 14.4 \\
\hline 3 & 3.0 & $2^{\prime}$ & 30 & 15.0 \\
\hline 4 & 3.0 & $2^{\prime} \quad 54^{\prime \prime}$ & 30 & 10.35 \\
\hline 5 & 3.5 & $2^{\prime} \quad 30^{\prime \prime}$ & 30 & 12.0 \\
\hline 6 & 4.0 & $2^{\prime} \quad 10^{\prime \prime}$ & 30 & 13.85 \\
\hline 7 & 5.0 & $5^{\prime} \quad 20^{\prime \prime}$ & 50 & 9.37 \\
\hline 8 & 5.5 & $5^{\prime} \quad 10^{\prime \prime}$ & 70 & 13.55 \\
\hline 9 & 6.0 & $4^{\prime} \quad 50^{\prime \prime}$ & 50 & 10.34 \\
\hline 10 & 6.5 & $4^{\prime} 31^{\prime \prime}$ & 50 & 11.07 \\
\hline 11 & 7.0 & $5^{\prime} \quad 40^{\prime \prime}$ & 70 & 12.35 \\
\hline 12 & 7.0 & $4^{\prime} \quad 44^{\prime \prime}$ & 60 & 12.68 \\
\hline 13 & 8.0 & $5^{\prime} \cdot 30^{\prime \prime}$ & 40 & 7.27 \\
\hline 14 & 8.0 & $9^{\prime} \quad 11^{\prime \prime}$ & 80 & 8.7 \\
\hline 15 & 10.0 & $5^{\prime}$ & 40 & 8.0 \\
\hline 16 & 14.0 & $7^{\prime} \quad 37^{\prime \prime}$ & 50 & 6.56 \\
\hline 17 & 20.0 & $4^{\prime} \quad 30^{\prime \prime}$ & 30 & 6.66 \\
\hline 18 & 23.0 & $3^{\prime} 2^{\prime \prime}$ & 20 & 6.6 \\
\hline 19 & 30.0 & \multirow{2}{*}{\multicolumn{3}{|c|}{ No movement within the period of observation }} \\
\hline 20 & 40.0 & & & \\
\hline
\end{tabular}

in the laboratory experiments, in the formation of aggregations and this might be related to some extent with the colony formation of this mussel in natural environments. If this is true, the effect of the movement must be very significant and the formation of colonies must have been nearly completed in the time when the component mussels of colonies are still very young, because the moving ability is generally more remarkable in juveniles than in adults.

However, there are noticeable differences in the condition between the laboratory experiments and the processes actually going on in the sea. The most significant must be the wave action in the latter. Moreover, there are some questions about the methods of the experiments carried out. Theoretically, the smaller the size of vessels is, the more frequently more than two mussels meet with one another and the higher the density of mussels within respective vessels is, the more frequent the chance of meeting of more than two mussels is. It is very questionable that the size of vessels for experiments and the density of mussels used for respective experiments were adequate so that the results of experiments can be compared with the natural behaviors of this mussel in the sea, if the effects of wave action could be put aside. 
Table 3. Aggregates formation of $H$. mutabilis in 24 hours.

\begin{tabular}{|c|c|c|c|c|c|c|}
\hline $\begin{array}{c}\text { Experiment No. } \\
\text { (date) }\end{array}$ & $\begin{array}{l}\text { Temperature } \\
\left({ }^{\circ} \mathrm{C}\right)^{*}\end{array}$ & $\begin{array}{c}\text { Shell length } \\
\text { in } \mathrm{mm}\end{array}$ & $\begin{array}{l}\text { No. of mussels } \\
\text { found solitarily }\end{array}$ & $\begin{array}{l}\text { No. of mussels } \\
\text { found in a } \\
\text { couple }\end{array}$ & $\begin{array}{l}\text { No. of mussels found in } \\
\text { groups of more than } 2 \\
\text { individuals } \\
\text { (No. of individuals in } \\
\text { respective groups) }\end{array}$ & $\begin{array}{l}\text { Total mussels } \\
\text { used in expe- } \\
\text { riment }\end{array}$ \\
\hline I (Jun. 17) & 21.2 & $3-5$ & 3 & 2 in 1 group & 5 in 1 group & 10 \\
\hline II (Jun. 21) & 21.1 & $5-20$ & 4 & 4 in 2 groups & 4 in 1 group & 12 \\
\hline III (Jun. 22) & 21.0 & $15-20$ & 2 & 2 in 1 group & 4 in 1 group & 8 \\
\hline IV (Jun. 25) & 21.2 & $5-10$ & 3 & 2 in 1 group & $\begin{array}{c}7 \text { in } 2 \text { groups } \\
(3,4)\end{array}$ & 12 \\
\hline $\mathrm{V}$ (Jun. 25) & 21.2 & $5-10$ & 4 & 2 in 1 group & $\begin{array}{c}6 \text { in } 2 \text { groups } \\
(3,3)\end{array}$ & 12 \\
\hline VI (Jul. 2) & 23.7 & $12-18$ & 3 & - & $\begin{array}{c}9 \text { in } 2 \text { groups } \\
(3,6)\end{array}$ & 12 \\
\hline VII (Jul. 25) & 27.1 & $3-6$ & 4 & 2 in 1 group & $\begin{array}{r}24 \text { in } 6 \text { groups } \\
(3,3,4,4,5,5)\end{array}$ & 30 \\
\hline VIII (Jul. 30) & 26.6 & $10-15$ & 4 & 4 in 2 groups & $\begin{array}{c}12 \text { in } 3 \text { groups } \\
(3,4,5)\end{array}$ & 20 \\
\hline
\end{tabular}

* Temperature measured at 9:00 A.M. 
Besides the moving ability of the mussel, the uneven or selective falling of spats and the complete destruction of spats fallen in unsuitable sites after the settling in a great density over the wide range of substratum can be other causes of colony formation. And further, it is not yet confirmed definitely whether the movements of this mussel are absolutely random or they are subject to a certain tropism. Thus, it is urged to trace the life history of this mussel exactly and to set more crucial experiments for tropisms to clear the colony formation of this mussel.

As mentioned already, the mussels once settled aggregated in the second and third series of experiments remained unchanged of their sites for several days after the regular observation was made. This seems to show that the mussels once attached firmly to the substratum or to one another will never move unless any abrupt change in the circumstances occurs. It is supposed that in the natural environments, the wave action may play the role of such abrupt changes for very small mussels. On the other hand, it has been noted that some mussels cut their byssi by themselves to move to some other site, leaving only the distal ends of byssi at the former site on the substratum. This occurred in some mussels which attached somewhat loosely to a plate submerged in a tank. Further, it was found that the rest of byssi inclusive of the byssus root was released out of the body by themselves (Fig. 2) and new byssi were secreted in some mussels which were collected on the day before. As the mussels were in unusual states in both cases, it is unknown whether or not such abilities are actually functional in the sea.

\section{Summary}

1. The moving ability of Hormomya mutabilis by foot was confirmed.

2. The moving activity is higher in juveniles than in adults.

3. Movements of mussels result in the formation of aggregates.

4. In forming aggregations, no preference to any special objects was recognized in the experiments here designed.

5. Self-cutting of the byssus and release of the whole byssus inclusive of the root were noted in some specimens.

\section{REFERENCES}

HARger, J.R.E. 1970. Comparisons among growth characteristics of two species of sea mussels, Mytilus edulis and Mytilus californianus. Veliger, vol. 13, no, 1, pp. 44-56.

Kuroda, T. and Habe, T. 1952. Check list and bibliography of the recent marine Mollusca of Japan. 210 pp. L.W. Stach, Tokyo.

Joosanoff, V.L. and Davis, H.C. 1963. Rearing of bivalve mollusks. In Advances in marine biology, edited by F.S. Russell, vol. 2, pp. 1-136, Academic Press, London. 